\title{
Immigrant Integration and Remittance Channel Choice
}

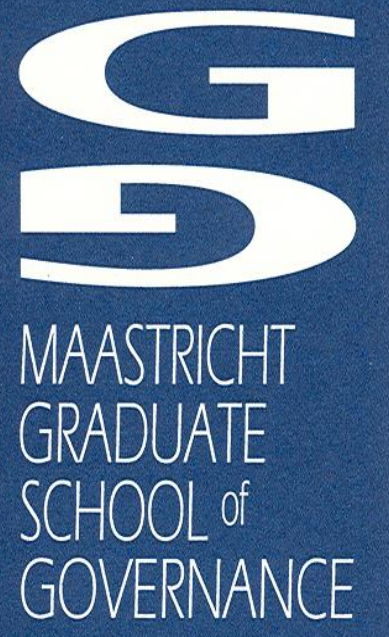

MARSTRCHT

GRADUATE SCHOOL o

GOVERNANCE
Melissa Siegel

\author{
Working Paper \\ MGSoG/2007/WP009
}

November 2007
Maastricht University

Maastricht Graduate School of Governance 


\title{
Maastricht Graduate School of Governance
}

The 'watch dog' role of the media, the impact of migration processes, health care access for children in developing countries, mitigation of the effects of Global Warming are typical examples of governance issues - issues to be tackled at the base; issues to be solved by creating and implementing effective policy.

The Maastricht Graduate School of Governance, Maastricht University, prepares students to pave the road for innovative policy developments in Europe and the world today.

Our master's and $\mathrm{PhD}$ programmes train you in analysing, monitoring and evaluating public policy in order to strengthen democratic governance in domestic and international organisations. The School carefully crafts its training activities to give national and international organisations, scholars and professionals the tools needed to harness the strengths of changing organisations and solve today's challenges, and more importantly, the ones of tomorrow.

\section{Author}

Melissa Siegel, PhD Fellow

Maastricht School of Governance

Maastricht University

Email: melissa.siegel@governance.unimaas.nl

\author{
Mailing address \\ Universiteit Maastricht \\ Maastricht Graduate School of Governance \\ P.O. Box 616 \\ 6200 MD Maastricht \\ The Netherlands

\section{Visiting address} \\ Kapoenstraat 2, $6211 \mathrm{KW}$ Maastricht \\ Phone: +31 433884650 \\ Fax: +31 433884864 \\ Email: info-gov@governance.unimaas.nl
}




\begin{abstract}
:
This paper empirically analyses to what extent the level of immigrant integration determines the channel chosen to send remittances (migrant money transfers). In recent years, there has been a large push by the international community to formalize remittances. For this reason, it is important to take note of the effect immigrant integration can have on the remittance channel choice. The data used in this study stems from the Dutch Consumentenbond survey conducted in 2005 which was specifically designed to focus on migrant remittances. This paper investigates immigrant integration at the migrant group level as well as the individual level. For the analysis, a relative measure of immigrant integration is constructed for six migrants groups, making use of various variables, which include: educational attainment, language ability, work force participation, migration history, and others. This ranking is then used to test the affect of the integration of minority ethnic groups living in the Netherlands on remittance channel choice. We hypothesize that the more integrated an ethnic group is in Dutch society, the more likely they are to remit formally (send money transfers through formal institutions). There may be a shift from informal to formal remittances when policies which enhance integration are put into place. This paper finds that the impact of immigrant integration is conditional on other factors. If the migrant sending country has put into place institutional policies (such as banks from the sending country in the host country) to keep close ties to migrants via remittances or if there is lack of access in the recipient country to formal transfers, integration has almost no influence on the remittance channel decision. For this reason, a combination of policies would be best able to tackle the task of incentivizing migrants towards more formal transfers.
\end{abstract}

Key words: remittances, money transfers, immigrant integration 


\section{Introduction}

This paper empirically analyses the degree of immigrant integration in determining the channel chosen to send remittances (migrant money transfers). In recent years, there has been increased interest by the international community (World Bank, IMF) to formalize remittances. This means a push to shift remittances from being sent informally (via cash couriers, underground banking, post, etc.) to being sent formally (through banks and money transfer operators like Western Union). Two main arguments in favor of the formalization of remittances are: 1) increased transparency in money transfers to counter money laundering and terrorist financing and 2) increased developmental impact of remittances moving through banks due to the extra multiplier effect and possibilities to use remittances as a guarantee for borrowing at the macro level. It is reasonable to assume that those immigrants that are more integrated in their host society are more comfortable with the host society's institutions. For this reason, it is important to analyze the effect immigrant integration can have on this choice which can then be incorporated into further policymaking.

The data used in this study stems from the Dutch Consumentenbond survey conducted in 2005. It is a survey specifically designed to focus on remittances and interviews the major immigrant populations in the Netherlands, which include: Moroccans, Turks, Surinamese, Antilleans, Somalis and Ghanaians. For the analysis, a relative measure of immigrant integration is constructed for the six immigrant population groups, using a mix of variables: educational attainment, language ability, work force participation, social relations with native population, legal rights and citizenship, political participation, and welfare dependency. This index is then used to analyze the effect of the level of integration of immigrant populations living in the Netherlands with regard to remittance channel choice.

There is a new emerging area of literature in cultural economics. Recent studies include the impact of culture on development (Tabellini, 2006), trade (Guiso, Sapienza, \& Zingales, 2006), growth (Barro \& McCleary, 2003; McCleary \& Barro, 2006), living arrangements (Giuliano, 2007), fertility and female labor force participation (Fernández \& Fogli, 2005), firms and employment (Bertrand \& Schoar, 2006) and economic behavior and attitudes (Alesina \& Giuliano, 2007). This paper contributes to the existing literature with a contribution looking at culture (immigrant origin) and remittance channel choice, a topic which has been left unexplored thus far.

The term integration may be interpreted in different ways, but for the purpose of this paper, the term is used as the degree to which immigrants become part of Dutch society. This paper looks at both socio-economic (usually measured by structural aspects including labor market position and education level) and socio-cultural aspects of integration. Social contacts and the degree to which immigrant groups participate in Dutch society are part of socio-cultural integration. It is more difficult to explore variables which affect socio-cultural integration than those related to socio-economic integration due to the difficulties with measurability, although, empirical research has shown that they are strongly correlated (Snel, Engbersen, \& Leerkes, 2006).

In this paper integration is considered at two different levels: the individual level and the ethnic group level. It is important to test both the individual and group level integration to see which factors are most important and to be able to draw conclusions at both levels. At the individual level it is hypothesized that the more integrated an individual is, the more likely 
that person will be to remit formally and particularly through banks. The specific variables used to test individual integration are whether or not the person was born in the Netherlands (hypothesizing that those born in the country will be more integrated because of growing up in the society), length of time the person has lived in the Netherlands (assuming that the longer the person has lived in the Netherlands, the more integrated they will be) and the migrant level of education (the greater the education the more integrated ${ }^{1}$ ). Tubergen, Maas, et al. (2004) found that education, work experience, language skills, age at time of migration and length of stay in the host country are important factors affecting economic (socioeconomic) integration. Migrants who move at a young age (or are born in the country), who have been living in the host country for many years, those with higher education, more work experience and better language skills usually have a better economic position in the host society.

Moving from individual integration to group level integration we hypothesize that the more integrated the immigrant group the more likely they will be to use formal channel and specifically banks since they should be more comfortable and familiar with the host country and its infrastructure. (Tubergen, Maas, \& Flap, 2004) found that even after taking into account individual characteristics, immigrants' economic position differs among origin groups in the host country. Evidence from the United States (Borjas, 1999) also shows that migrants' origin matters for economic integration. To measure this, we first look at many factors that may influence immigrant integration and make a ranking of group integration in the Netherlands. These findings are then used to statistically test which remittance channels the different migrant groups are using.

The main immigrant groups seen in Table 1 can be grouped into four different categories with regard to their migration: colonial migration (Surinamese and Antilleans), guest worker economic migration (Turks and Moroccans), later unrecruited economic labor migration (Ghanaian) and asylum seeker migration (Somalis). The Netherlands first saw the influx of unskilled migrants from Turkey ${ }^{2}$ (1963) and Morocco (1969) when the government recruited guest workers in the 1960s that were meant to stay in the Netherlands only a short period of time which was not what happened in reality (Guiraudon, Phalet, \& Wal, 2005). After 1973 the stock of Turks and Moroccans grew due to family reunification which peaked in 1979 and 1980. In the 1980s and 1990s the number of migrants from these two groups continued to increase due to marriage migration (marrying someone from the home country) (Vermeulen \& Penninx, 2000). As can be seen in Table 1, the Turks and Moroccans make up two of the most populous immigrant groups along with the Surinamese.

Although a tradition of immigration from Suriname to the Netherlands already existed, starting mainly in the 1960s, immigration picked up drastically around Surinamese independence in 1975 when citizens of Suriname were given the option of a Dutch or Surinamese citizenship and again in 1979-1980 when visa requirements were to be imposed on the Surinamese. Unskilled workers began migrated in 1965; those that had migrated previously were more highly skilled migrants. Immigration of Antilleans also began around the same time but peaked in the 1980s (Gijsberts, 2004). Migration in the 1960s was mainly students but the increase in the 1980s was due to the economic conditions in the country after several oil plants on the islands shut down, creating a difficult economic situation, which brought more low skilled workers.

\footnotetext{
${ }^{1}$ Age at migration would be another useful variable to look at which is not in the data set.

${ }^{2}$ For more background on Turks in the Netherlands and their labor market position, (Euwals, Dagevos, Gijsberts, \& Roodenburg, 2007)
} 
Ghanaian immigrants began their migration to the Netherlands in the 1980s when the economies of Ghana and Nigeria (the country to which they were migrating before) began to falter and picked up speed in the 1990s (Mazzucato, 2005). They see their time in the Netherlands as temporary and want to some day return to Ghana. The Ghanaians began with small community of migrants in the Netherlands which then led to chain migration. Much of the recent migration is due to family reunification and family formation (Kraan, 2001).

While the Somalis started to come to the Netherlands in great number in the 1990s, their reason for migration was quite different with the later migrating for economic reasons and the Somalis migrating as asylum seekers. There is much less information on the Ghanaians and Somalis in the literature and statistics than for the four major immigrant groups in the Netherlands (Surinamese, Turks, Moroccans and Antillean). This paper uses the sources available to create the most realistic picture possible.

Table 1: Ethnic make up in Dutch society (2005)-foreign origin-at least one parent born in another country

\begin{tabular}{|l|c|c|}
\hline & Frequency $(* 1000)$ & Percentage \\
\hline Moroccan & 316 & 27 \\
\hline Surinamese & 329 & 28 \\
\hline Antilleans & 131 & 11 \\
\hline Turks & 359 & 31 \\
\hline Ghanaians & $19^{3}$ & 2 \\
\hline Somalis & 22 & 2 \\
\hline Total & 1176 & 100 \\
\hline
\end{tabular}

Source: CBS Statline (Dutch Central Bureau for Statistics)

\section{An Index of Immigrant Integration in the Netherlands}

In this section immigrant integration of the six immigrant groups is ranked using indicators of integration. The final outcomes are summarized in Table $2^{4}$, which shows a rank order of integration with 1 being the most integrated in each category and 6 being the least integrated. The lower the total number at the end, the more integrated the immigrant group relative to the others. This is an ordinal ranking, so it is the place that matters and not the size.

Labor market participation and education are the two characteristics most cited as indicators of immigrant integration (albeit structural economic integration). In their introduction Vermeulen and Penninx (2000) display the labor market participation rate and employment rate for 1991 and 1998 for Turks, Moroccan, Surinamese and Antilleans. For both labor market participation and employment the Surinamese have the best showing with 66 percent participation in the labor force and a 58 percent employment rate in 1998. Antilleans are a close second with 62 percent and 53 percent respectively. Turks follow next with 47 percent and 37 percent while, in this comparison, Moroccans trail with only 44 percent and 34 percent

\footnotetext{
${ }^{3}$ While the official population of the Ghanaian population in the Netherlands is around 18,000, unofficially the population is closer to 40,000 due to many illegal migrants (Mazzucato, 2005).

${ }^{4}$ This table is not meant to be an exhaustive indication of all the variables that go into immigrant integration but to be a good indication of the integration situation. Other factors that may matter are relative group size, political situation in origin country, immigration policy in destination country, occupation and residential segregation.
} 
respectively. In Graph 1 and Table 1 of the Annex we see the same pattern over many years. The Ghanaians are relatively well educated but lack Dutch language skills and many are illegally living in the Netherlands. For this reason, many have jobs below their skill level in the informal economy or no jobs at all (Kraan, 2001). Chiswick and Miller (2001) show that refugees are less prepared and less ready for the labor market due to the circumstance of their migration (experiencing traumatic events and extreme stress in many cases). In the Netherlands, they are also not allowed to work while going through the asylum seeking process, putting Somalis last in the ranking.

When looking at educational attainment by immigrant group we see a similar picture with regard to performance as in the previous case. The Antilleans score slightly above the Surinamese with Turks and Moroccans following respectively. Graph 2 of the Annex elaborates on the completion of each level of education and highest completion rates. Refugees from Somalia are very poorly educated when compared to Turks and Moroccans (Gijsberts, 2004). This low level of education has put Somalis at a major disadvantage with regard to their possibility of obtaining employment. As previously stated, Ghanaians are relatively well educated.

Social relations with the native population are also important for integration; the more contact the immigrant group has with Dutch society, the more they will understand each other. One way to measure social relations with the host society is by looking at mixed marriages. Surinamese and Antilleans have more integrated social circles than the other groups. This can be illustrated by the marriage partners chosen by the different groups. Only $10 \%$ of Moroccans and Turks marry with Dutch natives whereas $40 \%$ of Surinamese marry Dutch and $60 \%$ of Antilleans enter into marriages with the native population (Gijsberts, 2004). The majority of Turks and Moroccans have married partners from their country of origin. In the period between 1990 and 2002, an estimated 60,000 marriage migrants entered the Netherlands from Turkey and Morocco (Gijsberts, 2004). This marriage migration is seen as hampering integration in to Dutch society due to lack of language skills and education of the new migrants as well as the obvious fact there is less interaction with the native population (Gijsberts, 2004). In general, Turks and Moroccans tend to have much more contact with people from their own ethnic group than contact with the indigenous Dutch. This is even more pronounced for the Turks who have a large degree of social control from their group. The Ghanaian are well organized in associations and organizations that focus on their ethnic identity and cultural habits (Kraan, 2001). Somalis also have a strong focus on their own ethnic group and are usually more segregated from Dutch society due to their migration status.

The notion of social distance, first put forth by Bogardus (1959), can be seen together with social relations, which suggests that people feel closer to some groups than others with regard to the degree of understanding between the two groups. According to Portes \& Rumbaut (2001) social distance depends to a great extent on culture, physical appearance and socioeconomic background. Religion is also known to play a role in social distance. In this case the Turks, Moroccans and Somalis would be the most culturally different since they come from a Muslim background, while the Surinamese and Antilleans have the closest social distance being part of or formally part of the Kingdom of the Netherlands. The Ghanaians fall in between these two groups.

Legal rights, citizenship and political participation in the host country are yet more factors that are considered here to be a measure of immigrant integration. Heelsum (2001) gives a 
good overview of the legal rights and citizenship of the four major immigrant groups. Immigrants from the former Dutch colonies have Dutch passports and have legal rights to politically participate. They have a right to vote in elections and to become a local or provincial councilor, parliamentarian or governor. Since 1992, Turks and Moroccans could have dual nationality. About two thirds of Turks and half of Moroccans enjoy this dual status. Those with Dutch passports have the same rights as the groups mentioned above for political participation. Those who are non-nationals but legally in the country have voting rights at the municipal level if they have living in the Netherlands for more than five years. Asylum seekers have no voting rights, but those who have gained refugee status have municipal voting rights after five years. Results from voting turn out in the local elections in 1994 and 1998 show that Turks participated most with as high as 67\% turnout in Amsterdam in 1994. The Moroccans were second and the Surinamese and Antilleans trailed behind. Due to the status and voting rights of Ghanaians (approximately half are illegal) and Somalis, there is much less possibility for them to participate in elections. In the table below, the Surinamese are placed with one point lower than the Antilleans due to there high representation in holding a political position (as councilors). The Turks and Moroccans follow the same pattern as with voting in this respect also.

Welfare dependency has also been sited as an indicator of integration. One third of the first generation of Turkish and Moroccan migrants and one fourth of the Surinamese and Antillean migrants are benefiting from social welfare (Gijsberts, 2004). The Ghanaians are to a large extent not benefiting from social assistance since they would have to have legal status in the country to benefit from such schemes. Somali refugees and asylum seekers, on the other hand, benefit largely from social welfare since in many cases they have no other option since they are not allowed to work while awaiting their verdict as an asylum seeker.

Immigrants who have already been exposed to the host country language before coming to the country are in a better position to learn the language than those who have not since the former arrives already familiar with the host language (Tubergen, Maas, \& Flap, 2004). Language skills can be seen as a part of human capital which has a positive impact on immigrant earnings and opportunities in the labor market (Kossoudji, 1988). It also makes sense that better language skills would increase immigrants' ability to speak with the native population making interethnic relations better (Espenshade \& Calhoun, 1993; Gordon, 1964).

The likelihood of return migration also plays a role in the immigrant's willingness to learn the host language (Chiswick \& Miller, 2001). This may partially explain why the Turks and Moroccans didn't put such a high importance on learning Dutch in the beginning as well as the current situation of the Ghanaians. A large number of Ghanaians speak English which has made it easier for them to migrate (Kraan, 2001) and has made it easier for them to continue to not speak Dutch. Since family reunification took even longer for the Moroccans, hoping that they would still return home one day, this may explain their relatively worse language position.

Table 2: Immigrant Integration Index 


\begin{tabular}{|c|c|c|c|c|c|c|c|c|}
\hline & 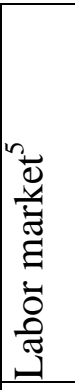 & 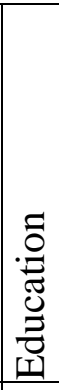 & 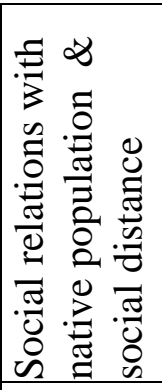 & 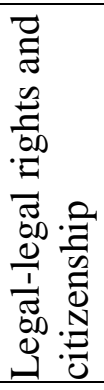 & 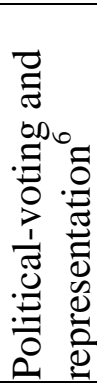 & 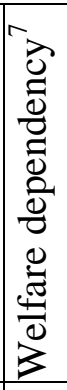 & 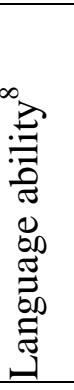 & 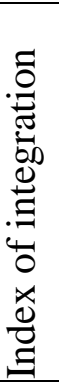 \\
\hline Surinamese & 1 & 2 & 2 & 1 & 2 & 2 & 1 & 11 \\
\hline Antilleans & 2 & 1 & 1 & 1 & 3 & 2 & 2 & 12 \\
\hline Turks & 3 & 3 & 3 & 2 & 1 & 4 & 4 & 20 \\
\hline Moroccans & 4 & 4 & 3 & 2 & 2 & 5 & 3 & 23 \\
\hline Ghanaians & 5 & 3 & 4 & 6 & 4 & 3 & 6 & 30 \\
\hline Somalis & 6 & 6 & 4 & 5 & 4 & 6 & 5 & 36 \\
\hline
\end{tabular}

From the results in Table 2 we see that the Surinamese and Antilleans come out as most integrated with Dutch society, while the index suggest that the Ghanaians and Somalis are least integrated. Turks and Moroccan fall in between. It is not unexpected to find the Surinamese as the most integrated group of immigrants. According to Gijsberts (2004), the Surinamese have progressed much more with regard to integration into Dutch society over the last several years than the Turks and Moroccans due to their education level, Dutch language ability, extent of family reunification and the size of the second and third generation among other factors. The Surinamese and Antilleans are socially and culturally closer to Dutch society than the Turks and the Moroccans which also has to do with differences in religious beliefs and values. While there can be some discussion about the indicators chosen here and the values assigned to each group, the ranking is robust and does not change with subtle shifts in values or variables.

\section{Remittance Channel Choice}

The survey data used in this paper was collected by Foquz Etnomarketing in 2005 (with the Consumentenbond ${ }^{9}$ as the project manager for the consumer data collection) which was funded by the $\mathrm{NCDO}^{10}$. A sample of 1336 remittance senders ${ }^{11}$ was used to collect data on remittance habits. The survey covers the six minority ethnic groups in the Netherlands: Moroccans, Turks, Surinamese, Antilleans, Ghanains and Somalis.

As can be seen in the Tables 3 and 4, banks are of great importance to Turkish migrants. In a paper by Köksal (2006) she gives an in-depth account of the importance of Turkish banks and the role the Central Bank of Turkey ${ }^{12}$ has played in "banking" Turks around the world. It is

\footnotetext{
${ }^{5}$ (Gijsberts, 2004)

${ }^{6}$ (Heelsum, 2001)

7 (Gijsberts, 2004)

${ }^{8}$ The relative better language position of Moroccan to Turks is found in (Tubergen \& Kalmijn, 2005)

${ }^{9}$ Dutch consumer advocacy group.

${ }^{10}$ NCDO stands for Nationale Commissie voor Internationale Samenwerking en Duurzame Ontwikkeling

(National Committee for International Cooperation and Sustainable Development).

${ }^{11}$ The breakdown of respondents by ethnic group can be seen in Table 2 of the Annex.

12 Turkish migrants abroad can open savings accounts at the Central Banks as well as having access to a range of other financial services (Köskal, 2006).
} 
important to note that while Turkish migrants use banks to a large extent, they are using their native banks and not the banks of the host country. It is important to keep this in mind for the resulting outcomes later in the paper.

Although the most important channel through which Moroccans send money is to carry it themselves, we also see that banks are an important channel for this migrant group, coming in as the second most important way to transfer money. This may be explained by the stable economic and political environment as well as particular policies the Moroccan government has set towards migrants (Haas \& Plug, 2006). Haas (2003) also finds similar results with regard to the little use of money transfer operators. Since the 1960s, the Moroccan government has encouraged the use of the formal financial sector with the creation of a network or consulates, bank branches and post offices to help assist money transfers. According to Haas and Plug (2006) remittance transfers through banks already replaced postal transfers in the 1980s and since the end of the 1980s the restrictions on money exchange and the repatriation of money have been lifted. Currency devaluations and fiscal policy favoring migrants have added in bringing remittances to Morocco through the banking sector. Moroccan banks have also increased their number of foreign offices because migrants are allowed to hold foreign exchange bank accounts with the Central Bank.

The Surinamese and Antilleans show similar remittance sending patterns. They both use money transfer operators (MTOs) as their primary method of sending money and send about 50 percent of remittances formally and the other 50 percent informally. Because of the difficult political situation in Somalia, there is very little access to formal means of sending money. Only 27 percent of transfers are sent formally. The majority of transfers go through hawala-type systems which are informal money transfer operators and through cash carried by the sender or someone else. The Ghanaians, on the other hand are the greatest users of formal services, although they are the lowest users of banks. On average, transfers are slightly more informal than formal on average.

Table 3: Ethnicity and channel table in percentages

\begin{tabular}{|l|c|c|c|c|c|c|c|}
\hline & Turks & Moroccans & Surinamese & Antilleans & Somalis & Ghanaians & Total \\
\hline MTO & 10 & 13 & $\mathbf{3 1}$ & $\mathbf{3 1}$ & 17 & $\mathbf{5 1}$ & $\mathbf{2 5}$ \\
\hline Bank & $\mathbf{3 8}$ & 25 & 19 & 22 & 10 & 6 & 21 \\
\hline Total formal & 48 & 38 & 50 & 53 & 27 & 57 & 46 \\
\hline $\begin{array}{l}\text { Self carried } \\
\text { cash }\end{array}$ & 25 & $\mathbf{3 0}$ & 18 & 14 & 17 & 16 & 13 \\
\hline $\begin{array}{l}\text { Call house, } \\
\text { travel agent, } \\
\text { other shop, } \\
\text { hawala }\end{array}$ & 7 & 4 & 13 & 9 & $\mathbf{3 1}$ & 20 \\
\hline $\begin{array}{l}\text { Other person } \\
\text { carried cash }\end{array}$ & 8 & 16 & 10 & 12 & 15 & 9 & 12 \\
\hline $\begin{array}{l}\text { Post (in letter } \\
\text { or package) }\end{array}$ & 4 & 4 & 8 & 9 & 3 & 2 & 5 \\
\hline $\begin{array}{l}\text { Mosque or } \\
\text { Church }\end{array}$ & 7 & 6 & 1 & 0 & 5 & 1 & 3 \\
\hline $\begin{array}{l}\text { Bank card or } \\
\text { credit card }\end{array}$ & 2 & 3 & 1 & 1 & 0 & 1 & 1 \\
\hline Total & 100 & 100 & 100 & 100 & 100 & 100 & 100 \\
\hline
\end{tabular}

Source: own calculation based on 2005 Consumentenbond survey

Table 4 shows that when banks are used to transfer money, different banks are chosen as the primary bank used for transferring money by different ethnic groups. ABN AMRO stands out 
as the most used with Postbank following close behind. Turks in particular use foreign (nonDutch) banks to transfer money, which are usually Turkish Banks.

Table 4: Ethnicity and bank usage in percentage

\begin{tabular}{|l|c|c|c|c|c|c|c|}
\hline & Turks & Moroccans & Surinamese & Antilleans & Somalis & Ghanaians & Total \\
\hline ABN AMRO & 19 & 31 & 39 & 29 & 29 & 15 & 28 \\
\hline Postbank & 7 & 26 & 26 & 37 & 47 & 46 & 24 \\
\hline $\begin{array}{l}\text { Foreign } \\
\text { banks }\end{array}$ & 52 & 5 & 4 & 2 & 12 & 8 & 21 \\
\hline Rabobank & 5 & 28 & 9 & 16 & 6 & 0 & 12 \\
\hline ING Bank & 5 & 3 & 13 & 4 & 6 & 0 & 6 \\
\hline SNS Bank & 7 & 7 & 7 & 8 & 0 & 0 & 6 \\
\hline Fortis Bank & 6 & 2 & 2 & 4 & 0 & 31 & 5 \\
\hline $\begin{array}{l}\text { Total } \\
\text { number of } \\
\text { respondents } \\
\text { using banks }\end{array}$ & 88 & 58 & 46 & 51 & 17 & 13 & 273 \\
\hline
\end{tabular}

Source: own calculation based on 2005 Consumentenbond survey

\section{Empirics}

\section{Formal vs. informal remittances}

First, the following equation is estimated using a probit model to find the determinants of the choice between formal and informal transfers.

$$
F_{i}=\alpha+\beta_{1} R_{i}+\beta_{2} C_{i}+\beta_{3} B_{i}+\varepsilon_{i}
$$

where $F_{i}$ is a dummy for formal channel choice. $R_{i}$ is remitter characteristics, $C_{i}$ is the country of origin and $B_{i}$ is remittance behavior.

In the table below we see that the effect of three of the immigrant groups is significant. The Moroccans, Surinamese and Somalis all show a significant preference for informal remittance sending and the Somalis have the largest marginal effect in this respect meaning that they have the highest preference for using informal services. As far as individual indicators are concerned, the greater the number of years a migrant has been in the Netherlands seems to correspond to a preference for informal transfers which goes against the original hypothesis of this paper. On the other hand, greater levels of education correspond with a choice for formal money transfer, which is in line with earlier reasoning. Sending money many times per year also corresponds with formal remittance channel usage.

Table 5: Probit for sending money formally

Turk

Moroccan

Surinamese

Antillean

Somali

Only male sent

Both sent

Age

\section{Marginal effect}

$-0.09$

$-0.15$

$-0.12$

$-0.05$

$-0.28$

0.04

$-0.01$

$-0.01$
Robust standard error
0.14
$0.15^{* * *} *$
$0.15^{* *}$
.014
$0.17 * * *$

0.11

0.12

0.02 
Age squared

Number of years in NL

Born in NL

Primary education

Lower secondary education

Secondary education

Vocational education

College education

University education

Sent between 2 and 4 times

per year

Sent between 5 and 11 times

per year

Sent 12 times per year

Sent 13 or more times per

year

Amount sent per year

Number of observations

Log pseudolikelihood

Pseudo R squared

Bases are: Ghanaian, female, no education, sent once per year

*significant at the $10 \%$ level

**significant at the $5 \%$ level

$* * *$ significant at the $1 \%$ level

Source: own calculation based on 2005 Consumentenbond survey

\section{Specific remittance channel}

The methodology for specific remittance channel choice draws on Amuedo-Dorantes (2005) . When looking at a remitter's transfer channel decision, each remitter $(i=1 \ldots n)$ derives utility $U_{i j}$ from any of the money transfer channels. In the first scenario, $j=1$ corresponds to banks, $j=2$ is MTO, $j=3$ is informal channels and $j=4$ are other methods of money transfer. The utility derived from a particular money transfer channel is as follows:

$$
U_{i j}=V_{i j}+\varepsilon_{i j}=\beta_{j}^{\prime} X_{i j}+\varepsilon_{i j}
$$

where $V_{i j}$ is the deterministic component and $\varepsilon_{i j}$ is the random component of the utility function. The probability of the $i$ th remitter choosing he $j$ th money transfer channel is equal to the probability of $U_{i j}$ being the largest of $U_{i 1}, \ldots U_{i 4}$ or $U_{i 1}, \ldots U_{i 9}$. So

$$
p_{i j}=\operatorname{Pr} o b\left(Y_{i}=j\right)=\operatorname{Pr} o b\left(U_{i j}>U_{i k}\right)=\operatorname{Pr} o b\left(\varepsilon_{i j}-\varepsilon i k \leq \beta_{j}^{\prime} X_{i j}-\beta_{k}^{\prime} X_{i k}\right),
$$

where $k=1 \ldots 4$ and $k \neq j$. The probability will depend on the assumptions made about the distribution of the random error terms $\left(\varepsilon_{j 1}, \ldots \varepsilon_{j 4}\right)$ or $\left(\varepsilon_{j 1}, \ldots \varepsilon_{j 9}\right)$. Therefore, the migrant's choice of money transfer channel is given by the probability:

$$
\operatorname{Pr} o b\left(Y_{i}=j\right)=\frac{\exp \left(\beta_{j^{\prime}} x_{i j}\right)}{\sum_{k=1}^{4} \exp \left(\beta_{k^{\prime}} x_{i j}\right)}
$$


where $j=1 \ldots 4$ is each remittance channel. MTOs are the base used in this model to obtain the relative risk ratios (also probability or odds ratios) of a corresponding change in the dependent variables. The ratio is as follows:

$$
\frac{P_{i j}}{P_{i k}}=\exp \left(\beta_{j^{\prime}} x_{i j}\right)
$$

Where $x_{i j}$ are the dependent variables and $k=j$ is the reference category.

In the next analysis we use the same three institutional categories as Amuedo-Dorantes (2005): 1) banks, 2) non-bank money transfers (MTOs), and 3) informal channels as the dependent variable. Here we go on to hypothesize on a more detailed breakdown of the formal channels group category. Since we are interested in not only the shift to the formal sector but also to the banking sector (for development reasons), it is important to look at the different motives to send through a bank or MTO. In equation 6, which measures the probability to use any of the channels over MTO, we keep the same independent variables as in the previous equation, but here we change the dependent variable into four choices where $T$ is the transfer channel: $T_{1}=$ bank transfer, $T_{2}=\mathrm{MTO}, T_{3}=$ informal transfer and $T_{4}=$ other transfers.

$$
T_{i}=\alpha+\beta_{1} M_{i}+\beta_{2} C_{i}+\beta_{3} B_{i}+\varepsilon_{i}
$$

In Table 6 we look at remittance channel choice, distinguishing between banks, MTOs and informal transfers. Since MTOs are used as the base, the results for bank and informal transfers are relative to MTOs. The table shows relative risk ratios (RRR) ${ }^{13}$ and robust standard errors. To better interpret the relative risk ratios, it is helpful to remember that the ratio is in the form of $P_{i \text {, bank }} / P_{i, \mathrm{MTO}}$ which indicates the probability of using a bank over a MTO. A ratio of 1 would mean that the two methods of sending money are equally likely. A value of less than $1\left(P_{i \text {, bank }}<P_{i, \mathrm{MTO}}\right)$ would mean that the bank is less likely to be used. For instance a risk ratio of 0.25 would imply that banks are less likely to be used than quick transfers with a ratio of 0.25 to 1 . On the other hand, a risk ratio greater than $1\left(P_{i \text {, bank }}>P_{i, \mathrm{MTO}}\right)$ would indicate the higher likelihood of the bank being used.

When compared with the base group (Ghanaians) each group is significantly more likely to use banks than MTOs and all but the Surinamese are more likely to use informal methods than MTOs. The situation with banks is particularly pronounced for the Turkish situation, with Turks being almost 36 times more likely to used Banks over MTOs. Moroccans also have a quite distinct preference for banks with a ration of 13 to 1 over MTOs.

Moving on to the individual characteristics, males (as the only members in the house who send remittances) seem to have a significantly higher likelihood of using banks, while when both men and women in the household are sending money, we see a preference for MTOs over informal transfers. Those people who have been in the Netherlands the longest are also those who are most likely to use banks over MTOs, which is in line with the original hypothesis. Education is significant across the board with people showing a much higher preference for MTOs over both banks and informal transfers. Those remitters who send money more often also have a significant preference for MTOs over informal transfers. Remitters sending money between 5 and 11 times per year were also more likely to use MTOs

\footnotetext{
${ }^{13}$ Relative risk ratios are also referred to as relative probabilities or odds ratios.
} 
while those who sent remittances at least 13 times per year were without a doubt making a choice for banks.

Table 6: Multinomial logit for channel choice with MTO base

Turk

Moroccan

Surinamese

Antillean

Somali

Only male sent

Both sent

Age

Age squared

Number of years in NL

Born in NL

Primary education

Lower secondary education

Secondary education

Vocational education

College education

University education

Sent between 2 and 4 times per year

Sent between 5 and 11 times per

year

Sent 12 times per year

Sent 13 or more times per year

Amount sent per year

Number of observations

Log pseudolikelihood

Pseudo R squared

Base: Ghana, female, no education, sent 1 time per year

*significant at the $10 \%$ level

**significant at the $5 \%$ level

$* * *$ significant at the $1 \%$ level

Marginal effects fist and robust standard error in parenthesis

Source: own calculation based on 2005 Consumentenbond survey

\section{8}

$-511.42$

0.18
Informal

32.68

2.83

$(1.35)^{* *}$

3.98

$(1.74)^{* * *}$

1.63

(0.69)

1.98

$(0.79)^{*}$

3.88

$(1.74) * * *$

0.85

$(0.25)$

0.61

$(0.20)^{*}$

0.97

(0.07)

1.00

(0.00)

1.01

$(0.02)$

0.93

$(0.36)$

0.00

$(0.00) * * *$

0.00

$(0.00)^{* * *}$

0.00

$(0.00) * * *$

0.00

$(0.00)^{* * *}$

0.00

$(0.00) * * *$

0.00

$(0.00)^{* * *}$

0.62

$(0.17)^{*}$

0.34

$(0.16)^{* *}$

0.00

$(0.00) * * *$

0.01

$(0.01)^{* * *}$

1.00

$(0.00)^{* *}$ 


\section{Concluding remarks}

In conclusion, immigrant integration is not the only factor in the channel decision. The paper does find that integration matters for the channel through which remittances are sent unless the migrant sending country has put into place institutional policies to keep close ties to migrants via remittances. We have witnessed this both cases of the Turks and the Moroccans. Turkey appears to be a particular case, resulting from the fact that Turks remit, to a large extent, through banks although they are one of the lesser integrated ethnic groups in the Netherlands. This can be explained by the fact that they are mostly served by their own native Turkish banks in the Netherlands. This finding implies that groups might be less integrated and still remit formally because the formal transfers are strongly embedded in their society. Policies which promote sending country involvement can increase the use of formal services, especially banks, and perhaps also facilitate banking the unbanked in the sending country since many migrant families back in the home country do not have bank accounts.

When we look at the rest of the results, the Surinamese and Antilleans (the most integrated groups) choose to remit through banks more often. The results for the decision to remit formally follow less with our theory, since our base group (Ghanaians) are the largest users of formal services (even thought these are almost entirely MTO transfers). Compared with this group everyone would prefer informal services, so it is then more interesting to look at the marginal effects of their choice. Here we see results more in line with the original hypothesis, since the least integrated group has the highest marginal effect for sending money informally.

It is important to keep in mind that immigrant integration is only one of the factors that influence remittance channel choice since people send money through different channels based also on what is available. In countries where there is little or no formal infrastructure for sending money, there is not even an option, regardless of how integrated the group is in Dutch society. This is blaringly obvious in the case of the Somalis.

Turning to the individual level integration factors, we see that education has a very positive impact on the decision to remit formally as well as the regular sending of remittances (so people become more used to the formal channels). Those remitters who send remittances more than 13 times per year were much more likely to use banks. The number of years a person had living in the Netherlands was also a significant factor in the decision to remit through banks as well as education level (although they also showed a preference for informal transfers over MTOs).

The overall findings of the relationship between immigrant integration and remittances channel choice gives some evidence for increased policies to help immigrant integration in host countries but the financial sector could also be used to help integration. In addition to all of the other social benefits of a socially cohesive society, we may see a shift from informal to formal remittances when such policies are put into place, although a combination of policies to also include institutions and infrastructure would be most beneficial. 


\section{References}

Alesina, A., \& Giuliano, P. (2007). The Power and the Family. National Bereau of Economic Research.

Amuedo-Dorantes, C. (2005). On the use of Differing Money Transmission Methods by Mexican Immigrants. International Migration Review, 39(3), 554-576.

Barro, R., \& McCleary, R. (2003). Religion and Economic Growth. American Sociological Review, 68, 760-781.

Bertrand, M., \& Schoar, A. (2006). The Role of the Family in Firms. Journal of Economic Perspectives, 20(2), 73-96.

Bogardus, E. S. (1959). Social Discance. Los Angeles, CA: Antioch Press.

Borjas, G. (1999). Heaven's Door: Immigration Policy and the American Economy. Princeton, NJ: Princeton University Press.

Chiswick, B. R., \& Miller, P. W. (2001). A Model of Destination Language Aquisition: Application to Male Immigrants in Canada. Demography, 38, 391-409.

Espenshade, T. T., \& Calhoun, C. A. (1993). An Analysis of Public Opinion toward Undocumented Immigration. Population Research and Policy Review, 12, 189-224.

Euwals, R., Dagevos, J., Gijsberts, M., \& Roodenburg, H. (2007). The Labor Market Position of Turkish Immigrants in Germany and the Netherlands: Reasons for Migration, Naturalisation and Language Proficiency CBS (Netherlands Bureau for Economic Policy Analysis) Discussion Paper.

Fernández, R., \& Fogli, A. (2005). Culture: An Emirical Investigation of Beliefs, Work and Fertility. NBER Working Paper, 11268.

Gijsberts, M. (2004). Ethnic Minorities and Integration: Outlook for the Future. The Hague: Social and Cultural Planning Office.

Giuliano, P. (2007). Living Arrangements in Western Europe: Does Cultural Origin Matter? Journal of the European Economic Association, 5(5), 927-952.

Gordon, M. M. (1964). Assimilation in American Life. New York: Oxford University Press.

Guiraudon, V., Phalet, K., \& Wal, J. t. (2005). Monitoring ethinic minorities in the Netherlands. UNESCO.

Guiso, L., Sapienza, P., \& Zingales, L. (2006). Does Culture Affect Economic Outcomes? Journal of Economic Perspectives, 20(2), 23-48.

Haas, H. d. (2003). Migration and Development in Southern Morocco: The Disparate SocioEconomic Impacts of Out-Migration on the Todgha Oasis Valley. Radboud University Nijmegen, Nijmegen.

Haas, H. d., \& Plug, R. (2006). Cherishing the Goose with the Golden Eggs: Trends in Migrant Remittances from Europe to Morocco 1970-2004. International Migration Review, 40(3), 603-634.

Heelsum, A. v. (2001). Political Participation of Migrants in the Netherlands. Paper presented at the Metropolis Conference, Rotterdam.

Köskal, N. E. (2006). Determinants and Impact on the Turkish Economy of Remittances. Working Paper.

Kossoudji, S. A. (1988). English Laguage Ability and the Labor Market Opportunities of Hispanic and East Asian Immigrant Men Journal of Labor Economics, 6, 205-228.

Kraan, M. (2001). Blijven of teruggaan? En sociologische analyse van potenties en problemen van Ghanezen in Amsterdam Zuidoost. Vrije Universiteit Amsterdam.

Mazzucato, V. (2005). Ghanaian migrants' double engagement: a transnational view of development and integration policies. Global Migration Perspectives, 48.

McCleary, R., \& Barro, R. (2006). Religion and Economy. Journal of Economic Perspectives, $20(2), 49 / 72$. 
Portes, A., \& Rumbaut, R. G. (2001). Legacies: The Story of the Immigrant Second Generation. Berkeley, CA: University of California Press.

Snel, E., Engbersen, G., \& Leerkes, A. (2006). Transnational involvement and social integration. Global Networks, 6(3), 285-308.

Tabellini, G. (2006). Culture and Institutions: Economic Development in the Regions of Europe. Working Paper.

Tubergen, F. v., \& Kalmijn, M. (2005). Destination-Language Proficiency in Cross-National Perspectives: A Study of Immigrant Groups in Nine Western Countries. American Journal of Sociology, 110(5), 1412-1457.

Tubergen, F. v., Maas, I., \& Flap, H. (2004). The Economic Incorporation of Immigrants in 18 Western Societies: Origin, destination, and Community Effects. American Sociological Review, 69, 704-727.

Vermeulen, H., \& Penninx, R. (2000). Immigrant Integration: The Dutch Case. Amsterdam: Het Spinhuis. 


\section{Annex}

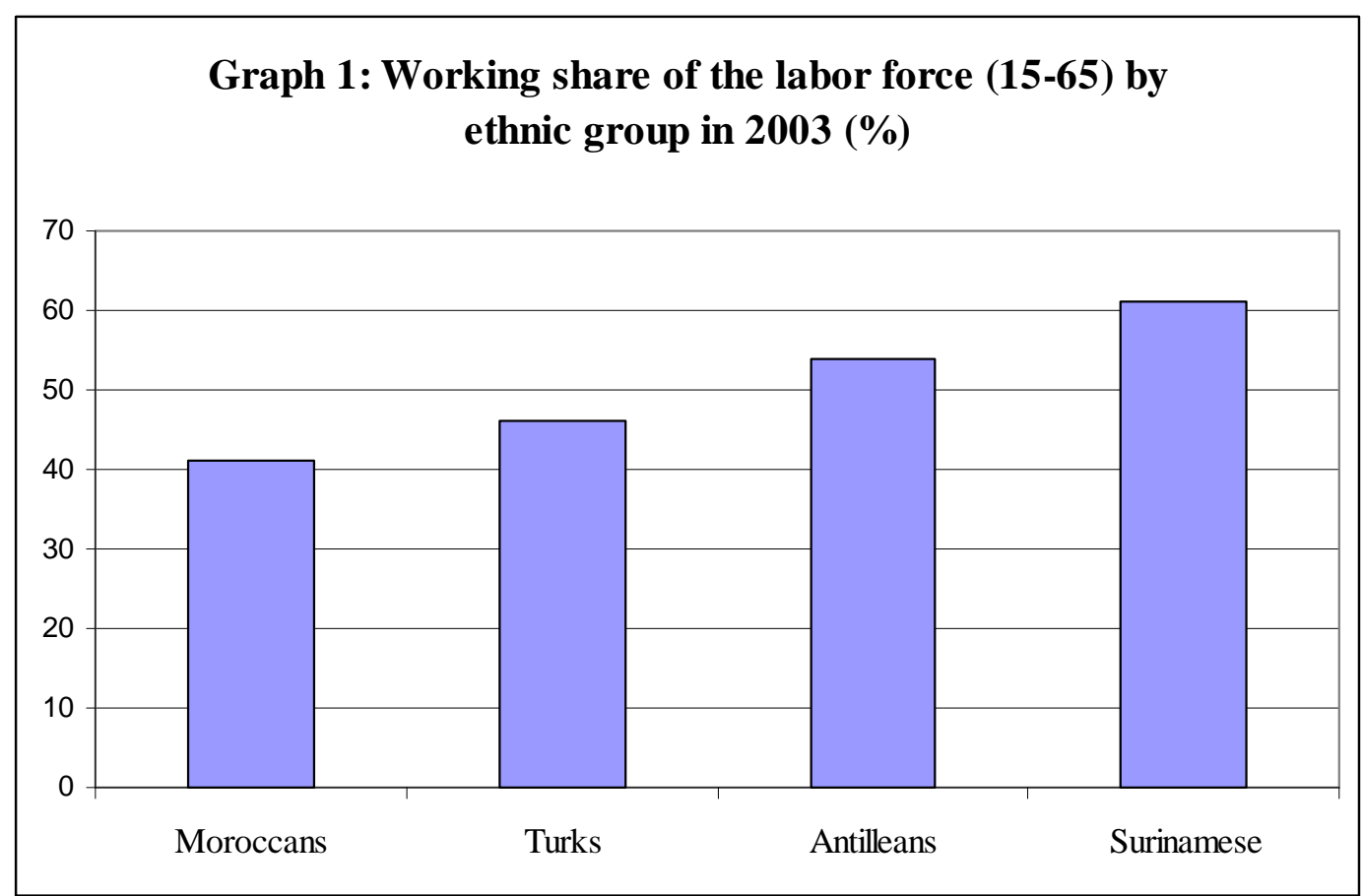

Source: SCP treatment (Dagevos et al. 2003) in (Gijsberts, 2004)

Table 1: Share of the total ethnic population (including non-workers) with a job of at least middle-ranking level, 1991-2002 (in percent)

\begin{tabular}{|l|c|c|c|c|}
\hline & 1991 & 1994 & 1998 & 2002 \\
\hline Turks & 7 & 10 & 9 & 13 \\
\hline Moroccans & 6 & 7 & 8 & 15 \\
\hline Surinamese & 19 & 21 & 28 & 32 \\
\hline Antilleans & 16 & 27 & 27 & 32 \\
\hline
\end{tabular}

Source: ISEO (SPVA'91 and '94); ISEO/SCP (SPVA '98 and '02); CBS (EBB '91,'02) in (Gijsberts 2004) 


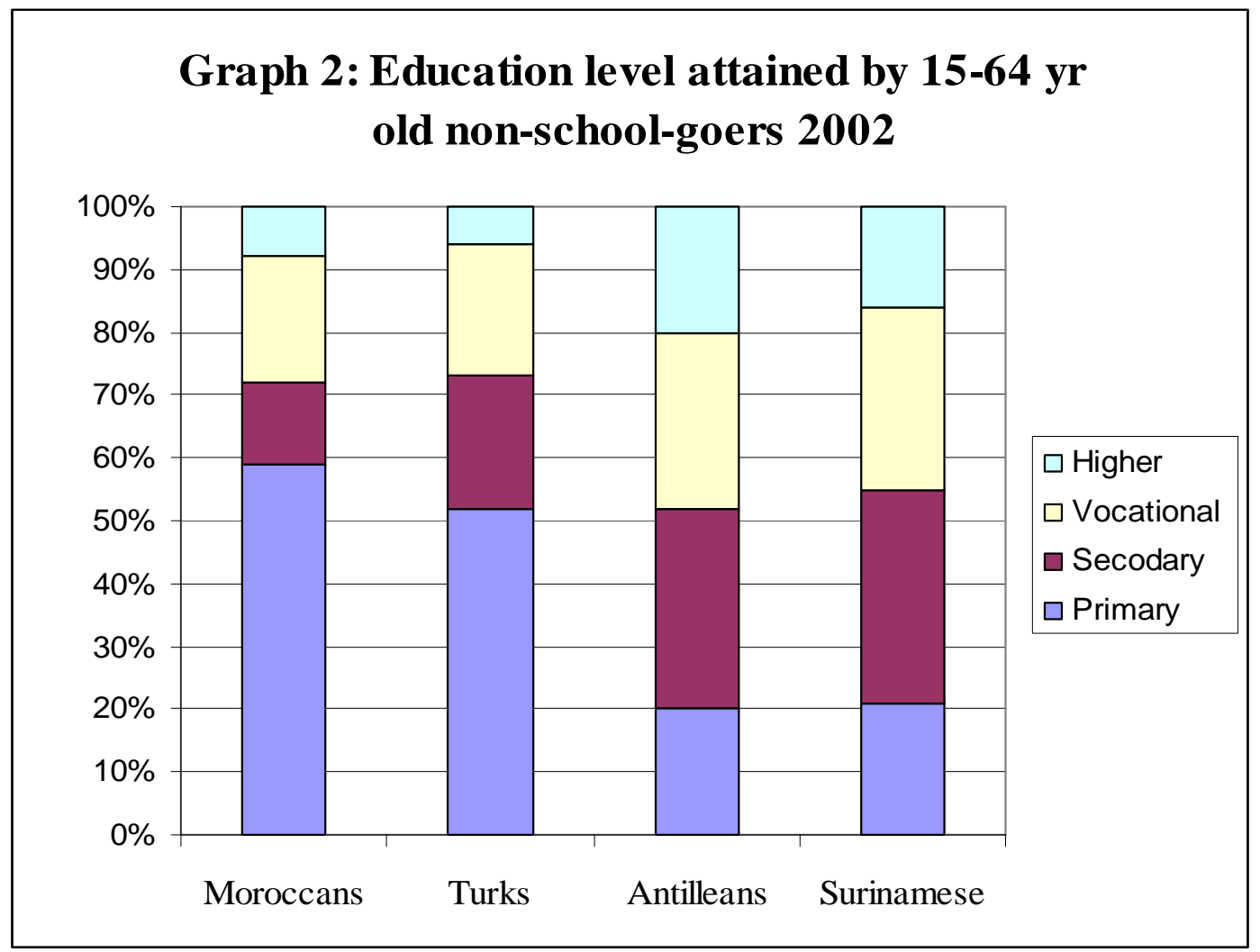

Source: ISEO/SCP (SPVA '02), CBS (EBB'02), SCP treatment (Degevos et al. 2003) in (Gijsberts, 2004)

Table 2: Ethnic make up of respondents

\begin{tabular}{|l|c|c|}
\hline & Frequency & Percentage \\
\hline Moroccan & 224 & 18 \\
\hline Surinamese & 243 & 18 \\
\hline Antilleans & 234 & 18 \\
\hline Turks & 229 & 17 \\
\hline Ghanaians & 211 & 16 \\
\hline Somalis & 175 & 13 \\
\hline Total & 1136 & 100 \\
\hline
\end{tabular}

Source: own calculation based on 2005 Consumentenbond survey 


\section{Maastricht Graduate School of Governance Working Paper Series}

\section{List of publications}

\begin{tabular}{lll}
$\begin{array}{l}\text { 2006 } \\
\text { No. }\end{array}$ & Author $(s)$ & Title \\
\hline 001 & $\begin{array}{l}\text { Gassmann, F. and } \\
\text { G. Notten }\end{array}$ & $\begin{array}{l}\text { Size matters: Poverty reduction effects of means-tested and } \\
\text { universal child benefits in Russia }\end{array}$ \\
\hline 002 & $\begin{array}{l}\text { Hagen-Zanker, J. } \\
\text { and } \\
\text { M.R. Muñiz Castillo }\end{array}$ & $\begin{array}{l}\text { Exploring multi-dimensional wellbeing and remittances in } \\
\text { El Salvador }\end{array}$ \\
\hline 003 & Augsburg, B. & $\begin{array}{l}\text { Econometric evaluation of the SEWA Bank in India: } \\
\text { Applying matching techniques based on the propensity } \\
\text { score }\end{array}$ \\
& & Poverty and consumption smoothing in Russia \\
\hline 004 & Notten, G. and & \\
& D. de Crombrugghe & \\
\hline
\end{tabular}

\begin{tabular}{|c|c|c|}
\hline No. & Author(s) & Title \\
\hline 001 & $\begin{array}{l}\text { Notten, G. and C. de } \\
\text { Neubourg }\end{array}$ & $\begin{array}{l}\text { Relative or absolute poverty in the US and EU? The battle } \\
\text { of the rates }\end{array}$ \\
\hline 002 & $\begin{array}{l}\text { Hodges, A. A. } \\
\text { Dufay, K. Dashdorj, } \\
\text { K.Y. Jong, T. } \\
\text { Mungun and U. } \\
\text { Budragchaa }\end{array}$ & $\begin{array}{l}\text { Child benefits and poverty reduction: Evidence from } \\
\text { Mongolia's Child Money Programme }\end{array}$ \\
\hline 003 & $\begin{array}{l}\text { Hagen-Zanker, J. } \\
\text { and Siegel, M. }\end{array}$ & The determinants of remittances: A review of the literature \\
\hline 004 & Notten, G. & $\begin{array}{l}\text { Managing risks: What Russian households do to smooth } \\
\text { consumption }\end{array}$ \\
\hline 005 & $\begin{array}{l}\text { Notten, G. and C. de } \\
\text { Neubourg }\end{array}$ & $\begin{array}{l}\text { Poverty in Europe and the USA: Exchanging official } \\
\text { measurement methods }\end{array}$ \\
\hline 006 & $\begin{array}{l}\text { Notten, G and C. de } \\
\text { Neubourg }\end{array}$ & $\begin{array}{l}\text { The policy relevance of absolute and relative poverty } \\
\text { headcounts: Whats in a number? }\end{array}$ \\
\hline 007 & $\begin{array}{l}\text { Hagen-Zanker, J. } \\
\text { and M. Siegel }\end{array}$ & $\begin{array}{l}\text { A critical discussion of the motivation to remit in Albania } \\
\text { and Moldova }\end{array}$ \\
\hline 008 & Wu, Treena & $\begin{array}{l}\text { Types of Households most vulnerable to physical and } \\
\text { economic threats: Case studies in Aceh after the Tsunami } \\
\text { (Theme 2) }\end{array}$ \\
\hline 009 & Siegel, $M$. & Immigrant Integration and Remittance Channel Choice \\
\hline
\end{tabular}

\section{8}

\begin{tabular}{lll} 
No. & Author $(s)$ & Title \\
\hline 001 & $\begin{array}{l}\text { Roelen, } \text { K. and } \\
\text { Gassmann, } F .\end{array}$ & $\begin{array}{l}\text { Measuring Child Poverty and Well-Being: a literature } \\
\text { review }\end{array}$
\end{tabular}

